\title{
Uluslararası Kızılhaç Komitesi'nin Uluslararası Nitelikte Olmayan Silahlı Çatışmalarda Faaliyetlerine İlişkin Bir Değerlendirme: Taraflara Hizmetlerini Teklif Etme Hakkı
}

\author{
An evaluation of Involvement of the International Committee of the Red \\ Cross in the Non-International Armed Conflicts: Right to Offer its Services
}

Meltem Sarıbeyoğlu Skalar* (iD)

\section{öz}

Uluslararası nitelikte olmayan silahlı çatışmalarda Uluslararası Kızılhaç Komitesi’nin çatışmanın taraflarına hizmetlerini teklif etme hakkı bulunmaktadır. Bu hak 1949 Cenevre Sözleșmeleri’nin ortak 3’üncü Maddesi ile açıkça öngörülmüştür. Uluslararası nitelikte olmayan silahlı çatışmaların doğası gereği hizmetlerin teklif edilebileceği taraflar sadece Cenevre Sözleşmeleri’nin tarafı devletler değil, aynı zamanda onlarla mücadele eden devlet-dışı silahlı gruplardır. Bu grupların gerek Birleşmiş Milletler gibi uluslararası örgütler gerekse devletlerin iç hukuklarında terör örgütü olarak listelenmesi Uluslararası Kızılhaç Komitesi’nin ortak 3’üncü Maddede öngörülen işlevi açısından zorluklar doğurmaktadır. Makalede Uluslararası Kızılhaç Komitesi’nin devlet-dışı silahlı gruplarla angajmanına ilişkin yaklaşımı ve karşılaştığı zorluklara ilişkin nedenler değerlendirilmektedir.

Anahtar Kelimeler: Muhasamatta Doğrudan Yer Alma, Devlet-Dışı Silahlı Gruplar, Uluslararası Nitelikte Olmayan Silahlı Çatışma, Uluslararası İnsancıl Hukuk, ICRC

\section{ABSTRACT}

International Committee of the Red Cross has a right to offer its services to the parties of a noninternational armed conflict. This right was explicitly stipulated by the common Article 3 of the 1949 Geneva Conventions. In accordance with the nature of the non-international armed conflicts, recipients of these services, would be not only the State parties to the Conventions but also various non-State armed groups that are fighting with them. Often those non-state armed groups are listed as terrorist organizations by the intergovernmental organizations such as the United Nations as well as they are regulated under the domestic criminal law of the State parties. Thus, this creates challenges in respect of the Commitee's function under the common Article 3. The paper investigates the International Committee of the Red Cross' approach with regard to its engagement with the non-State armed groups and evaluates the grounds for challenges for the organization while performing a highly sensitive task.

Anahtar Kelimeler: Direct Participation in Hostilities, Non-State Armed Groups, Non-International Armed Conflict, International Humanitarian Law, ICRC

\footnotetext{
* Doç. Dr., Marmara Üniversitesi Hukuk Fakültesi, Milletlerarası Hukuk Anabilim Dalı öğretim üyesi Sorumlu Yazar/Correspondence Author: Meltem Sarıbeyoğlu Skalar
}

E-posta/E-mail: meltem.saribeyoglu@marmara.edu.tr 


\section{Giriş}

Günümüzde silahlı çatışmaların büyük çoğunluğu, devletler arasında veya en azından doğrudan devletler arasında değil, devletler ile silahlı gruplar veya bir devlet ülkesinde çeşitli silahlı gruplar arasında cereyan etmektedir. Bilindiği gibi devlet-dışı silahlı grupların dâhil olduğu silahlı çatışmalar yeni bir olgu değildir. Tarihte en bilinen örnekleri olarak 19'uncu ve 20'nci yüzyıllarda Amerikan ve İspanyol iç savaşları ile Kolombiya ve Sri Lanka'da uzun zamana yayılmış iç çatışmaların yanı sıra günümüzde de özellikle Orta Doğu ve Sahel Bölgelerine hâkim olan iç çatışmalar hemen akla gelen örnekler arasındadır. 1949 yılında Cenevre Sözleşmeleri imzalanırken, bu türden silahlı çatışmalara uygulanmak üzere, dört Cenevre Sözleşmesi’nde aynı şekilde yer alan ortak 3'üncü Madde öngörülmüştür. Cenevre Sözleşmeleri’nin 3'üncü Maddesi uluslararası nitelikte olmayan bir silahlı çatışmanın tarafları ifadesini içermekte ve Uluslararası Kızılhaç Komitesi'ni, yaralı ve hastaların toplanması ve bakımı başta olmak üzere, çatışmanın taraflarına hizmetlerini teklif etmek üzere yetkilendirmektedir.

Bu olgulardan hareketle, Uluslararası Kızılhaç Komitesi (ICRC) Mart 2021'de “ICRC’nin Devlet-dışı Silahlı Gruplarla Angajmanı: Neden, nasıl, ne amaçla ve diğer öne çıkan sorunlar” başlığını taşıyan bir Görüş Belgesi ${ }^{1}$ yayımlamıştır. Bu belge ile uzun zamandır bu kapsamda yürüttüğü faaliyetleri ve dayandığı esasları açıklamaktadır. Bu makalede söz konusu bilgi metninin içeriğine ilişkin bir değerlendirme yapılacaktır. Bunun için, öncelikle uluslararası nitelikte olmayan silahlı çatışma kavramıyla ilgili belirleyici esaslar kısaca açıklanmaktadır. İkinci olarak ICRC’nin uluslararası nitelikte olmayan silahlı çatışmalarda görevinin kapsamı ve Görüş Belgesi’nde yer alan hususlar ele alınmaktadır. Son olarak konuya ilişkin bir değerlendirmeye yer verilmiştir.

\section{ULUSLARARASINITELIKTE OLMAYAN SILAHLIÇATIŞMALARIN BELIRLENMESi}

1949 Cenevre Sözleşmeleri'nin² Ortak 3’üncü Maddesi'nde uluslararası nitelikte olmayan silahlı çatışmaların tanımına yer verilmemiştir. ${ }^{3}$ Kavramı daha somut hale getiren 1949 Cenevre Sözleşmelerine Ek II No.'lu Protokol ${ }^{4}$ de yine kısmen tanımlanmayı gerektiren terimler

1 ICRC Engagement with Non-State Armed Groups: Why, how, for what purpose, and other salient issues ICRC Position Paper, March 2021. (Bundan böyle Görüş Belgesi olarak anılacaktır.) https://www.icrc.org/sites/default/files/ wysiwyg/Activities/Humanitarian-diplomacy/icrc_engagement_with_non-state_armed_groups_position_paper.pdf. (13.03.2021)

2 Harp Halindeki Silahlı Kuvvetlerin Hasta ve Yaralılarının Vaziyetlerinin Islahı Hakkında Cenevre Sözleşmesi; Silahlı Kuvvetlerin Denizdeki Hasta; Yaralı ve Kazazedelerinin Vaziyetlerinin Islahı Hakkında Cenevre Sözleşmesi; Harp Esirlerine Yapılacak Muamele ile ilgili Cenevre Sözleşmesi, Harp Zamanında Sivillerin Korunmasına ilişkin Cenevre Sözleşmesi, Cenevre, 12 Ağustos 1949; R.G. 30 Ocak 1953 - 8322, Düstur: III. Tertip, C.34. 1949.

3 Uluslararası nitelikte olmayan silahlı çatışmalara ilişkin detaylı açıklamalar için bkz. Fatma TAŞDEMİR, Uluslararası Nitelikte Olmayan Silahlı Çatışmalar Hukuku, Adalet Yayınevi, Ankara, 2009; Ayşe Nur TÜTÜNCÜ, İnsancıl Hukuka Giriș, Beta, İstanbul, 2006.

412 Ağustos 1949 Tarihli Cenevre Sözleşmelerine Ek Uluslararası Silahlı Çatışmaların Mağdurlarının Korunmasına İlişkin Protokol (I No.'lu Protokol); 12 Ağustos 1949 Tarihli Cenevre Sözleşmelerine Ek Uluslararası Olmayan Silahlı Çatışma Mağdurlarının Korunmasına İlişkin Protokol, Cenevre, 8 Haziran 1977. Cenevre Sözleşmelerinin gözden geçirilmiş Türkçe metni ve Ek Protokollerin tercüme metinleri için bkz. Melike BATUR YAMANER et al., 12 Ağustos 1949 Tarihli Cenevre Sözleşmeleri ve Ek Protokolleri, Galatasaray Üniversitesi Hukuk Fakültesi Yayını 42, İstanbul. 
içermektedir. Cenevre Sözleşmeleri’nde, bu kavram açılığğ kavuşturulamadığ 1 için birçok farklı yorum ortaya çıkmış ve sıklıkla ortak 3'üncü Maddenin uygulanabilirliği de inkâr edilmiştir. Böylece, uluslararası nitelikte olmayan silahlı çatışmalarda mağdurların durumunu iyileştirmek için gerek kuralları oluşturmak gerekse de bu kuralların uygulanabilir olup olmadıkları hakkında objektif kriterler belirleyerek, devletlerin bu konuda takdir hakkını sınırlamak gereği ortaya çıkmıştır. ${ }^{5}$

1949 Cenevre Sözleşmeleri’nin Ortak 3'üncü Maddesi "Milletlerarası mahiyette olmayan bir silâhlı anlaşmazlığın Yüksek Âkit Taraflardan birinin toprakları üzerinde çıkması halinde" şeklindeki düzenlemesiyle 2'nci Maddeye gönderme yapmış olmaktadır. Böylece uluslararası nitelikte olmayan bir silahlı çatışma, Sözleşmèye taraf bir devletin ülkesinde cereyan eden fakat taraflarının her biri devlet olmayan bir silahlı çatı̧̧madır. II No.'lu Protokol'ün 1'inci Maddesi, "bir Yüksek Âkit tarafın ülkesinde kendi silahlı kuvvetleriyle muhalif silahlı kuvvetler veya sorumlu komuta altında olan, devamlılık arz eden ve planlı askeri operasyonlar yapmalarına ve bu Protokolü uygulamalarına imkân verecek şekilde bu Yüksek Âkit tarafın ülkesinin ait bir kısmı üzerinde kontrolü elinde bulunduran diğer örgütlü silahlı gruplar arasında cereyan eden tüm silahlı çatışmalarda uygulanır" düzenlemesini öngörmektedir. ${ }^{6} \mathrm{Bu}$ düzenleme, Ortak 3’üncü Maddenin getirdiği koşulları değiştirmeden, geliştiren ve tamamlayan şekilde uygulanacaktır. ${ }^{7}$ Ayrıca, bu düzenleme, I No.lu Ek Protokol'ün l'inci Maddesinin 4'üncü fikrası altında uluslararası silahlı çatışma olarak sayılan ulusal bağımsızlık savaşlarına da uygulanamaz.

Bir devlet ülkesinde vuku bulan şiddet olaylarının bir iç silahlı çatı̧̧ma olarak nitelendirilebilmesi için iki kriter dikkate alınacaktır: Silahlı çatışmaların belli bir yoğunlukta tezahür etmesi ve devletdışı silahlı grupların örgütlenme seviyesi. ${ }^{8}$ Bu belli ağırlığı veya yoğunluğu belirlemede dikkate alınan etkenler; silahlı çatışmaların ciddiyeti ve süresi, hükümet kuvvetlerinin niteliği - askeri kuvvetlerin kullanılıp kullanılmadığı - kullanılan silahların tipi, sivillerin geniş ölçekte yer değiştirmeleri, muhalif güçlerin belli bir ülke kesiminde kontrol sağlaması, verilen kayıp miktarı ve zararın büyüklüğü gibi çeşitli faktörlerdir. ${ }^{9}$ Diğer değerlendirilmesi gereken etken ise silahlı çatışmanın tarafı olan devletdışı silahlı grubun örgütlenme seviyesidir. Burada dikkate alınan etkenler arasında, bir komuta zincirinin varlığı, farklı birimleri birlikte kullanabilen şekilde operasyon düzenleme kapasitesi, yeni kişileri silah altına alma, eğitme ve donatma, iç işleyiş kurallarının varlığı gibi unsurlar sayılabilir. ${ }^{10}$ II No.'lu Ek Protokol'de öngörülen bu iki kriterin iç silahlı çatışmaları belirlemede daraltıcı bir etki yaptığı da gözlemlenebilir. Bu görüş doğrultusunda, bir iç silahlı çatışma, II No.'lu Ek Protokol'deki bu koşulları karşılamasa bile 1949 Cenevre Sözleşmeleri’nin ortak 3’üncü Maddesinin uygulama

5 Yves SANDOZ/Christophe SWINARSKI/Bruno ZIMMERMANN, Commentary on the Additional Protocols of 8 June 1977 to the Geneva Conventions of 12 August 1949, ICRC, Geneva, 1987, s. 1348, para. 4448.

6 Türkçe metin ve Ek Protokollerin tercüme metinleri için bkz. Melike BATUR YAMANER et al., supra dn. 4.

$7 \quad$ Protokol No. II Madde 1.

8 Ibid.

9 Sylvain VITE', “Typology of armed conflicts in international humanitarian law: legal concepts and actual Situations", International Review of the Red Cross, Volume 91 Number 873 March 2009, s. 76. 
alanına girebilir. Diğer yandan, II No.'lu Ek Protokol'ün uygulandığı tüm silahlı çatışmalara 1949 Cenevre Sözleşmeleri'nin ortak 3'üncü Maddesi de uygulanır. ${ }^{11}$

Uluslararası nitelikte olmayan bir silahlı çatışmanın bir devlet ülkesinde tezahür eden ve yukarıda sözü edilen yoğunluğa ulaşmayan diğer toplumsal şiddet olaylarından da ayırt edilmesi gereklidir. II No.'lu Ek Protokol'ün 1'inci Maddesinin 1'inci fikrasında öngörülen kriterlerin varlığ 1 , iç karışıklık (internal disturbances) ve iç gerginlik (internal tensions) durumlarını, iç silahlı çatışmaların tanımından dışlamak için yeterlidir. ${ }^{12}$ Bu kavramların tanımı II No.'lu Ek Protokol'de yer almamıştır. ICRC tarafından temelde kendi iç işleyişi gerektirdiğinden bu tanımlar yapılmıştır. İç karışıklık ve gerginlikler uluslararası insancıl hukukun uygulama alanına girmemektedir. Ancak bu her tür uluslararası hukuk kuralından muaf oldukları anlamına gelmez, zira bu tür durumlarda uluslararası evrensel ve bölgesel insan hakları antlaşmaları uygulama alanı bulacaktır. ${ }^{13}$

$\mathrm{Bu}$ bölümde bahsedilen uluslararası nitelikte olmayan silahlı çatışmalara örnek olarak, 2012'de Mali’nin kuzeyinde Mali silahlı kuvvetleri ile silahlı gruplar arasında gerçekleşen çatışmalar ve Suriye'de Suriye hükümet güçleri ile silahlı gruplar arasında vuku bulan çatışmalar anılabilir. ${ }^{14}$

\section{ULUSLARARASI NITELIKTE OLMAYAN SILAHLI ÇATIŞMALARDA ULUSLARARASI KIZILHAÇ KOMITESI'NIN GÖREVI}

Uluslararası Kızılhaç Komitesi, “ICRC’nin Devlet-dışı Silahlı Gruplarla Angajmanı: Neden, nasıl, ne amaçla ve diğer öne çıkan sorunlar” başlıklı Görüş Belgesi’nde, sivillerin bulunduğu bölgelere erişim açısından devlet-dışı silahlı gruplarla angajmanını bir önkoşul olarak ele almıştır. ${ }^{15}$ Buna göre, insancıl misyonunun gerektirdiği şekilde, sivil kişilere ve nüfusa koruma ve yardım ulaştırabilmek için, bu sivillerin bulunduğu ülke kesimlerinde operasyonlarını yürüten ve bu ülke kesimlerini kontrolleri altında tutan devlet-dışı silahlı gruplarla iletişim kurması gerektiğini açıklamaktadır. Görüş Belgesi’nde genel olarak koruma faaliyetleri altında anılan hususlar, uluslararası insancıl hukuka riayetin sağlanması, kopan aile bağlarının yeniden kurulması, kayıp çocukların araştırılması, ölenlerin kimlik tespiti ve defni, tutukluların kaydı ve ziyaret edilmesi ve benzeri faaliyetler olarak sayılmıştır. Geniş anlamıyla yardım ise gıda dağıtımı ve geçim kaynaklarının oluşturulmasından, su kaynakları ve su arıtma tesislerine, hastanelerin desteklenmesi ve işletilmesinden, ortopedi ve harp cerrahisi gibi hizmetlerin teminine kadar birçok hususu kapsamaktadır. ${ }^{16}$ Aslında görüldüğü gibi Görüş Belgesi’nde örnek olarak sayılan yardım faaliyetleri, uluslararası bir silahlı çatışmada tahayyül edilebilecek yardım faaliyetlerinden farklı değildir.

11 Ibid., s. 79.

12 SANDOZ/SWINARSKI/ZIMMERMANN, op. cit. s. 1354, para. 4472.

13 Ibid., s. 1356, para. 4479. Ayrıca bkz. Emre ÖKTEM, Terörizm, İnsancıl Hukuk ve İnsan Hakları, Derin Yayınları, İstanbul, 2007.

14 Kathleen LAWAND, Interview - What is a non-international armed conflict?, https://www.icrc.org/en/doc/resources/ documents/interview/2012/12-10-niac-non-international-armed-conflict.htm. (13.03.2021)

15 Görüş Belgesi, supra dn. 1, s. 2.

16 Ibid., s. 5. 
Diğer yandan, Görüş Belgesi’nde siviller veya sivil nüfus olarak anılan kişilerin tanımı, geçmiş çalışma ve belgelerde pek çok fikir ayrılığına neden olmuştur. Konu devletler açısından zaten hassas bir olguya ilişkinken ayrıca sivil tanımının, iç silahlı çatışmalar açısından, adeta geçişli bir muğlaklık içeren yorumu başka sorunları beraberinde getirmiştir. ${ }^{17} \mathrm{Bu}$ şekilde korunan kişilerin tespitine ilişkin kriterler, 1949 Cenevre Sözleşmeleri’nin Ortak 3’üncü Maddesinin yorumuyla ilgili çalışmalarda tartışmalı görüşlerin ortaya çıkmasına yol açmıştır. Aşağıda öncelikle Ortak 3’üncü Maddede korunan kişilerin tanımı ele alınmıştır. İkinci olarak ICRC’nin bir devlet ülkesinde faaliyet gösteren çeşitli silahlı gruplarla angajmanına ilişkin Görüş Belgesi’nde yer alan hukuki gerekçelere yer verilmiştir.

\section{A. ORTAK 3'ÜNCÜ MADDE ILE KORUNAN KIŞILER}

1949 Cenevre Sözleşmeleri’nin Ortak 3'üncü Maddesi “muhasamata doğrudan doğruya iştirak etmeyen şahıslara" koruma sağlamaktadır. Bu kişiler, çatışmalarda aktif şekilde yer almayan hors de combat durumda kalmış kişiler veya tıbbi veya dini personel gibi sivillerdir. ${ }^{18} \mathrm{O}$ halde, siviller çatışmalarda aktif şekilde yer aldıkları süre boyunca ortak 3’üncü Maddenin sağladı̆̆ korumadan yararlanamazlar, fakat çatışmalarda aktif yer almaya son verdikleri durumda, hastalık, yaralanma, tutuklanma veya diğer herhangi bir nedenle hors de combat duruma geldikleri andan itibaren koruma altına girerler. ${ }^{19} \mathrm{Bu}$ kapsamda sivil nüfus kavramına silahlı güçlerin, bu gruplardan ayrılmış eski üyeleri de dâhildir. ${ }^{20}$ Tahmin edilebileceği gibi, Sözleşmelerin bağlayıcı olmayan 2016 Yorumunda, sivil nüfusun böyle bir kapsamla ve genel şekilde tanımlanması birçok tartışmayı da beraberinde getirmiştir. 2016 Yorumunun benimsediği bu görüş Uluslararası Kızılhaç Komitesi ve T.M.C. Asser enstitüsünün düzenlediği uzmanlar toplantılarının bir ürünü olarak derlenen ve 2009 yılında yayımlanan Uluslararası İnsancıl Hukukta Muhasamata Doğrudan Katılım Kavramının Yorumlanmasına Yönelik Rehber'de yer verilen görüşlere dayanmaktadır. ${ }^{21}$ Bu konudaki tartışmalar aşağıda değerlendirme bölümünde ele alınmaktadır.

Sivillere ilaveten ortak 3’üncü Maddenin koruduğu ikinci kategori, silahlı güçlerin savaşçı statüsünde olmayan üyeleri (tıbbi ve dini personel sadece bu işlerde görev almak koşuluyla) ${ }^{22}$ ile "silâhlarını terkeden silâhlı kuvvetler mensuplarıyle hastalık, yaralanma, mevkufiyet dolayısiyle veya sair herhangi bir sebeple harp dışı edilmiş bulunan şahıslar” da bu korumadan ${ }^{23}$ yararlanmaktadırlar.

17 Bkz. infra Ortak 3'üncü Madde ile Korunan Kişiler.

18 Uluslararası Ceza Mahkemesi Statüsü Madde 8(2)(c) altında düzenlenmiş tüm suçların unsurları aynıdır. Bkz. International Criminal Court (ICC), Elements of Crimes, 2011, https://asp.icc-cpi.int/iccdocs/asp_docs/Publications/ Compendium/ElementsOfCrime-ENG.pdf. (13.03.2021)

19 ICRC, Commentary on the First Geneva Convention: Convention (I) for the Amelioration of the Condition of the Wounded and Sick in Armed Forces in the Field, 2nd edition, 2016, Common Article 3, para. 521. https://ihldatabases.icrc.org/ihl/full/GCI-commentary. (13.03.2021)

20 Ibid.

21 Nils MELZER, Interpretive guidance on the notion of direct participation in hostilities under international humanitarian law, ICRC, 2009, s.72-73. http://www.icrc.org/eng/assets/files/other/icrc-002-0990.pdf. (13.03.2021)

22 ICRC, Commentary on the First Geneva Convention, op. cit., para. 522.

23 ICRC, Commentary on the First Geneva Convention, op. cit., para. 523. 
Muhasamata doğrudan katılma kavramı ne ortak 3’üncü Maddede ne de 1949 Cenevre Sözleşmeleri veya önceki antlaşmaların herhangi bir hükmünde tanımlanmıştır. Ancak, muhasamata doğrudan iştirak eden kişiler ile iştirak etmeyen veya daha fazla iştirak etmeyen kişilerin ayırt edilmesi (principle of distinction) insancıl hukukun dayandı $\breve{g}_{1}$ temel ilkelerdendir. ${ }^{24}$

Muhasamata katılma kavramına 1977 Ek Protokollerinde de rastlanabilir. ${ }^{25}$ I No.'lu Protokol'ün 51'inci Maddesinin 3'üncü fikrasında ve II No.'lu Protokol'ün 13'üncü Maddesinin 3'üncü fikrasında sivillerin "muhasamatta doğrudan yer almadıkça ve almadıkları zaman süresince" (unless and for such time as they take a direct part in hostilities) askeri operasyonların yol açtığı tehlikelere karşı korunmaları gerektiği bildirilmektedir. Yine Uluslararası Kızılhaç Komitesi’nin Uluslararası İnsancıl Teamül (Örf-Adet) Hukuku üzerine çalışmasında, 6’ncı Kural “[s]iviller, muhasamata doğrudan katılmaları durumu hariç, saldırılara karşı koruma altındadır” demektedir. ${ }^{26}$ Ortak 3'üncü Maddenin İngilizce metninde kullanılan muhasamata aktif (active) katılım ile Ek Protokoller'de kullanılan muhasamata doğrudan (direct) katılım ifadelerinin aynı anlama geldiği genel olarak kabul görmektedir. ${ }^{27}$

Muhasamata Doğrudan Katılım Kavramının Yorumlanmasına Yönelik Rehber'de bir eylemin muhasamata doğrudan katılım teşkil etmesi için üç kurucu unsuru birlikte taşıması gerektiği ileri sürülmüştür:

- Eylem, çatışmanın bir tarafının askeri operasyonlarını ya da askeri yeteneklerini olumsuz yönde etkileyebilecek olmalı ya da doğrudan saldırıya karşı korunan kişi ya da objelerde ölüm, yaralanma ya da zarara neden olmalıdır. (zarar eşiği)

- Eylem ya da eylemin bir ayrılmaz/bütünleşik bir parçasını oluşturduğu koordine bir askeri operasyon ile neden olması beklenen zarar arasında nedensellik bağı bulunmalıdır. (doğrudan nedensellik)

- Eylem, çatışmanın bir tarafına destek için ve öbür tarafın aleyhine olacak şekilde zarar eşiğine doğrudan yol açmak üzere özel olarak tasarlanmalıdır. (savaşla alakalı olmak) ${ }^{28}$

Ayırt etme ilkesi uluslararası silahlı çatışmalara ilişkin olarak 1949 Cenevre Sözleşmeleri’ne Ek I No.'lu Protokol'ün 48'inci Maddesinde kodifiye edilmiştir. Buna göre, "Sivil halkın ve sivil nitelikte malların saygı görmesini ve korunmasını sağlamak için, çatışmanın Tarafları daima, sivil halk ile muharipleri, sivil mallar ile askeri hedefleri birbirinden ayırt etmeli ve buna uygun olarak operasyonlarını sadece

24 ICRC, Commentary on the First Geneva Convention, op. cit., para. 524.

25 I No.'lu Ek Protokol, Madde 51(3) ve II No.'lu Ek Protokol, Madde 13(3). Ayrica bkz. Jean-Marie HENCKAERTS ve Louise DOSWALD-BECK, Uluslararası İnsancıl Teamül (Örf-Adet) Hukuku, Cilt I: Kurallar, (çev) A. Emre ÖKTEM et al., Galatasaray Üniversitesi Hukuk Fakültesi Yayınları 66, İstanbul, 2005, Kural 6. Ibid.

27 ICRC, Commentary on the First Geneva Convention, op. cit., para. 525.

28 MELZER, Interpretive guidance op. cit., s. 46'dan aktaran ve tercüme eden Bleda Rıza KURTDARCAN, Muharebe Alanının Yeni Aktörleri: Askeri Yükleniciler, Beta, İstanbul, 2017. Muhasamata doğrudan katılım kavramının detaylı bir analizi için bkz. KURTDARCAN, ss. 400-410. 
askerî hedeflere yöneltmelidirler."29 I No.'lu Ek Protokol'ün 51'inci Maddesinin 2'nci fikrası ise "Sivil halk ve bireysel olarak siviller saldırının hedefi olmayacaktır. Esas amacı sivil halk arasında terör yaymak olan şiddet hareketleri ya da tehditleri yasaktır" ${ }^{30}$ demek suretiyle özellikle sivilleri korumayı amaçlamıştır. Bu hükümler aynı zamanda uluslararası insancıl hukuk alanında örf ve adet hukukunu ${ }^{31}$ da yansıttıklarından antlaşmanın tarafı olmayan devletler açısından da bağlayıcıdırlar. ${ }^{32}$ Uluslararası nitelikte olmayan silahlı çatışmalar açısından da yine aynı şekilde, II No.'lu Protokol'ün 13'üncü Maddesinin 2'nci fikrasının yanı sıra, örf ve adet hukukundan doğan bir yükümlülüğün bulunduğu söylenebilir. ${ }^{33}$

Yukarıda da belirtildiği gibi, I No.'lu Protokol'ün 51'inci Maddesinin 3’üncü fikrasında ve II No.'lu Protokol'ün 13'üncü Maddesinin 3'üncü fikrasında sivillerin "muhasamatta doğrudan yer almadıkça ve almadıkları zaman süresince" (unless and for such time as they take a direct part in hostilities) askeri saldırılara karşı korunmaları düzenlenmiştir. Böylece muhasamatta doğrudan yer alan sivillerin, sivil nüfusa dâhil olma durumları son bulmaz ancak doğrudan saldırılara karşı korunmaları geçici şekilde askıya alınır. Muhasamata Doğrudan Katılım Kavramının Yorumlanmasına Yönelik Rehber'de bu hususa ilişkin olarak aşağıda yer verilen ve Rehber'in hazırlanmasına katılan birçok uzmanın sonradan imzalarını geri çekmelerine neden olan bir yorum kabul edilmiştir. ${ }^{34}$ Buna göre, "yer almadıkça ve almadıkları zaman süresince" (unless and for such time) ifadesi, korumanın askıya alınmasını, söz konusu sivilin doğrudan muhasamatta yer alma süresi ile sınırlamıştır. Bu da "döner kapı" (revolving door) metaforuyla anılan, sivillerin belirli aralıklarla muhasamatta doğrudan yer alması olgusuna bağlı olarak, askeri saldırılara karşı koruma kazanıp kaybetmesi döngüsünü ifade etmektedir. Muhasamata Doğrudan Katılım Kavramının Yorumlanmasına Yönelik Rehber'de sivillerin korunmasının "döner kapısı" olarak anılan bu durum uluslararası insancıl hukukun bir eksikliği değil doğal bir parçası olarak nitelendirilmiştir. ${ }^{35} \mathrm{Bu}$ yaklaşım, o belirli anda, askeri bir tehdit oluşturmayan sivilleri saldırılara karşı korumaktadır. Bahsedilen bireysel sivillerin değişken durumu, çatışmanın taraflarından biri yararına muhasamatta yer alma durumu süreklilik arz eden organize silahlı grupların mensuplarından farklıdır. Bu nedenle de öngörmek bir hayli güçtür. Zira, bir sivilin ister zorla ister gönüllü şekilde olsun, muhasamatta defalarca dahi yer almış olması, gelecekte nasıl bir tavır benimseyeceği yönünde kesin bir bilgi vermeyecektir. ${ }^{36}$

29 Maddenin Türkçe tercümesi için bkz. BATUR YAMANER, et al., op. cit., s. 212.

30 Maddenin Türkçe tercümesi için bkz. BATUR YAMANER, op. cit., s. 213.

31 Anılan kurallar şu şekilde tespit edilmiştir:

Kural 1. - Bir çatışmanın tarafları, siviller ile muharipleri her zaman birbirinden ayırt etmek zorundadır. Saldırılar yalnızca muhariplere yönelik olabilir. Sivillere karşı saldırı yapılamaz.

Kural 2. - Asıl amacı sivil halk içinde terör yaratmak olan şiddet eylem ya da tehditleri yasaktır.

Kural 7. - Çatışmaya taraf olanlar, her zaman, sivil mallar ile askeri hedefleri birbirinden ayırt etmek zorundadır. Saldırılar yalnızca askeri hedeflere yönelik olmalıdır. Saldırılar sivil nitelikteki mallara yönelik olamaz. Bkz. HENCKAERTS ve DOSWALD-BECK, supra dn. 26.

32 Michael SCHMITT, “The Interpretive Guidance on the Notion of Direct Participation in Hostilities: A Critical Analysis”, Harvard National Security Journal, Vol. 1, 2010, s. 12. Ibid.

34 MELZER, op. cit., s. 70.

35 Benimsenen bu anlayışın eleștirisi için bkz. SCHMITT, loc. cit.

36 MELZER, op. cit., s. 71. 
Muhasamatta doğrudan yer alma kavramı spesifik düşmanca fiillere işaret ettiği için, uluslararası insancıl hukuk, bir sivilin korunmasını, onun her bir muhasamatta doğrudan iştirakinin son bulmasından sonra, yeniden tesis etmektedir. Bu doğrultuda, Rehber'e göre, bir sivil muhasamatta tekrar doğrudan yer alıncaya kadar, kendisine kolluk kuvvetlerinin uyguladı̆̆ 1 tedbirlere ait standartlar ve bireysel meşru müdafaa hükümleri uygulanmalıdır.

Uluslararası nitelikte olmayan silahlı çatışmalara taraf devlet-dışı örgütlenmiş silahlı gruplara mensup olan siviller ise "sürekli bir savaş işlevine" sahiplerse sivil niteliklerini kaybederler. Böylece sivillere muhasamatta doğrudan "yer almadıkça ve almadıkları zaman süresince” sağlanan korumadan artık yararlanamazlar. ${ }^{37}$ Korumanın kaybedilmesini spesifik düşmanlık fiillerinin sürdüğü zaman zarfıyla sınırlandıran anlayış, sivillerin karıştığı spontan, düzensiz veya örgütsüz düşmanlık fiillerini kastetmektedir ve bu nedenle örgütlü silahlı gruplara uygulanamaz. ${ }^{38}$ Aksi takdirde, devletlerin düzenli silahlı kuvvetleri, bu niteliklerinden ötürü sürekli şekilde askeri saldırıların hedefi olabilirken, devlet-dışı silahlı gruplar, gündüz çiftçi, gece muharip bir işleyiş şekli benimseyebilirler ki bu uluslararası insancıl hukukun izin verdiği bir durum olamaz. ${ }^{39}$

Sivillerin, spontan, düzensiz veya örgütsüz düşmanlık fiilleriyle muhasamatta doğrudan yer almanın ötesine geçerek, bir iç silahlı çatışmaya taraf bir devlet-dışı silahlı grubun üyesi olması durumunda ise bu grubun üyesi olarak kaldıkları müddetçe uluslararası insancıl hukuk altında koruma hükümlerinden yararlanamayacaklardır. Bu durumda korumanın “döner kapısı” üye olup olmama üzerine işlemektedir. Bir silahlı gruptan ayrılma ise açıcça beyan etmeyi gerektirmese de gruptan kendisini sürekli olarak uzak tutmak ve sivil hayata tekrar entegre olmak gibi verilerle belirlenebilir. ${ }^{40}$ Son olarak Rehber, bir sivilin belli bir zaman diliminde, korumadan yararlanır durumda mı yoksa yoksun durumda mı olduğunun belirlenmesi açısından iyi niyetli ve mevcut verileri dikkatle araştıran bir incelemenin yapılmasını önermektedir ve şüphe durumunda sivillerin koruma hükümlerinden yararlandığının farzedilmesi gerektiğini bildirmektedir. ${ }^{41}$

\section{B. ULUSLARARASI KIZILHAÇ KOMITESI'NIN DEVLET-DIŞI SILAHLI GRUPLARLA ANGAJMANINA ILIŞKIN GÖRÜŞ BELGESI}

Uluslararası Kızılhaç Komitesi Mart 2021'de “ICRC’nin Devlet-dışı Silahlı Gruplarla Angajmanı: Neden, nasıl, ne amaçla ve diğer öne çıkan sorunlar” başlı̆̆ını taşıyan bir Görüş Belgesi ${ }^{42}$ yayımlamıştır. Görüş Belgesi’nde, uluslararası nitelikte olmayan silahlı çatışmalarda ICRC’nin neden devlet-dışı gruplarla ilişki kurmak ihtiyacı içinde olduğu ve bu ihtiyacın arkaplanı; silahlı grupların kontrol ettiği ülke kesimlerinde sivillere erişim ve uluslararası insancıl hukuka riayet konusunda

37 Ibid.

38 Ibid., ss. 71-72.

39 Ibid., s. 72.

40 Ibid.

41 Ibid., s. 73.

42 Görüş Belgesi, supra dn. 1. 
devlet-dışı grupların bilgilendirilmesi; bu gruplarla angajmandan kaynaklı sorunlar ve angajmanın hukuki dayanağ gibi konular açıklanmıştır.

ICRC’nin devlet-dışı silahlı gruplarla angajman ihtimalini değerlendirdiği durumlarda, başlıca sebebin, bu grupların faaliyet gösterdiği bölgelerde nüfus ve kişiler üzerinde potansiyel olumsuz etkiler olduğu söylenmektedir. ${ }^{43}$ Buna göre, ICRC’nin bu gruplarla angajmanı insancıl gerekliliklerden kaynaklanmakta ve eğer ihtiyaç içindeki nüfusun acılarını azaltacak bir yardım faaliyeti yürütülecekse angajmanın zorunlu olduğu bildirilmektedir. Görüş Belgesi’nde bu hususlar şu dört noktada açıklanmıştır:

- Angajman, ilk olarak ICRC’nin uluslararası nitelikte olmayan silahlı çatışmadan veya diğer bir şiddet durumundan etkilenen ve silahlı bir grubun faaliyette bulunduğu veya kontrol ettiği bir ülke kesiminde bulunup korunma ve yardım ihtiyacı içinde olan nüfuslara ve kişilere erişmesi için bir önkoşuldur.

- İkincisi, angajman, silahlı bir grubun, ICRC’nin bağımsız, nötr ve tarafsız bir insancıl organizasyon olduğunu anlamasını ve kabul etmesini ve insancıl görevlerini güvenli şekilde icra etmesine izin vermesini temin etmek için esastır.

- Üçüncüsü, angajman, hukuka saygı gösterilmesini sağlamak için uluslararası insancıl hukuku ve ilgili diğer yasal araçları tanıtmak ve böylelikle uluslararası nitelikte olmayan bir silahlı çatışmanın ve diğer şiddet olaylarının mağdurlarının çektiği acıları engellemek veya hafifletmek için bir önkoşuldur.

- Dördüncüsü, ICRC 1949 Cenevre Sözleşmeleri’nde, uluslararası nitelikte olmayan bir silahlı çatışmanın taraflarına, devlet-dışı silahlı gruplar da dahil, hizmetlerini önerebilecek bir örgüt örneği olarak açıkça ismi anılan tek tarafsız insancıl organizasyondur. ${ }^{44}$

ICRC’nin bu tür silahlı gruplarla angajmanına ilşkin hukuki gerekçeler ise ayrı bir başlık altında toplanmıştır. Belge'de, uluslararası nitelikte olmayan silahlı çatışmaların ve bunlarda rol oynayan devletdışı silahlı grupların sayısındaki artış her ne kadar nispeten yeni olsa da uluslararası insancıl hukukun bu konuyu düzenlemeleri arasına alması 1949 yılına uzanmaktadır denilmektedir. ${ }^{45}$ Gerçekten 1949 Cenevre Sözleşmeleri’nin içinde “mini-sözleşme” olarak da anılan ortak 3'üncü madde “[m]illetlerarası mahiyette olmayan bir silâhlı anlaşmazlık" durumuna hasredilmiştir. Madde insani muamele ilkesini ortaya koymakta ve anlaşmazlığa taraf teşkil edenlerden her biri[nin], en az olarak" uygulamakla yükümlü olduğu hükümleri saymaktadır. Bu hükümler ise, hayata yönelik saldırıları, zalimane muamele ve işkenceyi, rehin alma ve kişi onuruna karşı muameleleri ve yargısal güvenceler bulunmaksızın cezaya maruz bırakılmayı yasaklamaktadır. ${ }^{46}$ Ortak 3’üncü Madde ICRC ’’ye, uluslararası nitelikte olmayan

43 Ibid., s. 2.

44 Ibid., ss. 2-3.

45 Ibid., s. 9.

46 Madde 3 fikra 1 (a-d). 
bir silahlı çatışmanın her iki tarafıyla ve dolayısıyla bir devlet-dışı silahlı grupla da angaje olabileceği bir görevi açıklıkla vermektedir. Ortak 3'üncü Madde’nin 2'nci fikrasına göre, "Milletlerarası Kızılhaç Komitesi gibi tarafsız insani bir teşkilât, anlaşmazlık halinde taraflara hizmetlerini arz edebilecektir". Burada, ICRC’nin teklif edebileceği hizmetler sayılmamıştır ancak sahadaki insani acıları ve ihtiyaçları gidermeye yönelik her tür insancll faaliyeti taraflara teklif etme konusunda ICRC yasal bir hakka sahiptir. Ancak tarafların, ICRCnin insancil hizmetlerini sunma teklifini kabul etme gibi bir yükümlülüğü ise bulunmamaktadır. Görüş Belgesỉnde, uluslararası nitelikte olmayan bir silahlı çatışmada, ICRC nin bu tür bir insancıl yardım teklifinin, dostça olmayan bir girişim veya hukuka aykırı bir müdahale olarak görülmemesi gerektiği ve yine, keyfi şekilde reddedilmemesi gerektiği düşünceleri yer bulmuştur. ${ }^{47}$ Görüş Belgesi’nde vurgulanan husus, ICRC'nin bu tür bir yaklaşımının devlet egemenliğini ihlal veya ihlal tehdidi olarak görülmemesi gerektiğidir.

Uluslararası nitelikte olmayan silahlı çatı̧̧malar konusuna hasredilmiş Cenevre Sözleşmeleri’ne Ek 1977 II No.'lu Protokol ise 1'inci Maddesinin 1'inci fikrasında, ortak 3'üncü Maddeyi “mevcut uygulama koşullarını değiştirmeden, geliştiren ve tamamlayan" özellikte olduğunu bildirmiştir. Bu nedenle, II No.lu Ek Protokol'ün uygulama alanına giren uluslararası nitelikte olmayan silahlı çatışmaların varlığı durumunda, ICRC, hizmetlerini gerek devletlere gerekse de devlet-dışı silahlı gruplara teklif edebilir tespiti de Görüş Belgesi’nde yer almıştır. ${ }^{48}$

Uluslararası insancil hukuk kurallarının uygulanması ve ICRC nin hizmetlerini teklif etmesi "tarafların hukukî durumları üzerinde bir tesir icra etmeyecektir"49. Ortak 3'üncü Maddedeki bu açık ifade, bir iç çatışmada uluslararası insancıl hukuk kurallarının uygulanmasından ötürü, devletdışı bir silahlı grubun tanınması, hukuki statüsü veya hukuki veya siyasi meşruiyeti üzerine hiçbir değişiklik olmayacağına ilişkin devletlerin endişelerini gidermek için konulmuştur. Görüş Belgesi, tutarlı uygulamayla da bu kuralın doğrulandığını bildirmektedir. Ayrıca uluslararası insancıl hukuk, bir devletin devlet-dışı silahlı gruplarla tüm hukuka uygun araçları kullanmak suretiyle mücadele etme hakkını sınırlandırmadığı gibi silahlı grubun üyelerini, işledikleri suçlardan dolayı iç hukuka göre yargılama ve cezalandırma hakkını da etkilememektedir. ${ }^{50}$ Görüş Belgesi, ICRC nin hizmetlerini, devlet-dışı bir silahlı gruba teklif etmesi halinde, karşı taraftan kabul görmesi için öncelikle bu grupla bir diyalog yürütmek zorunda olduğunu ifade etmektedir. Görüş Belgesi, yukarıda aktarılan hukuki dayanaklara bir kez daha gönderme yapmak suretiyle, ICRC’nin ortak 3'üncü Maddede öngörülen görevinin devlet-dışı silahlı gruplarla da angajmanını gerektirdiğini ve bu gruplarla yürütülen diyaloğun bu gruplara herhangi bir meşruiyet kazandırmadığını belirtmektedir. Burada elde edilen sonucun, sadece, bu grupların, sivilleri koruma aracı olarak hukuka daha fazla saygı göstermelerini sağlamaya yönelik olduğunu açıklamaktadır. ${ }^{51}$

47 Görüş Belgesi, supra dn. 1, s. 10.

48 Ibid.

49 Harp Halindeki Silahlı Kuvvetlerin Hasta ve Yaralılarının Vaziyetlerinin Islahı Hakkında Cenevre Sözleşmesi; Silahlı Kuvvetlerin Denizdeki Hasta, Yaralı ve Kazazedelerinin Vaziyetlerinin Islahı Hakkında Cenevre Sözleşmesi; Harp Esirlerine Yapılacak Muamele ile ilgili Cenevre Sözleşmesi, Harp Zamanında Sivillerin Korunmasına ilişkin Cenevre Sözleşmesi, ortak Madde 3 para. 2/son.

50 Görüş Belgesi, supra dn. 1, s. 10.

51 Ibid. 
Görüş Belgesinin son bölümünde, ICRC’nin bahsedilen faaliyet alanında karşılaştığ başlıca güncel zorluklar aktarılmıştır. ${ }^{52}$ Ortak 3’üncü Maddenin sınıflandırması açısından bir iç çatışmanın uluslararası nitelikte olmayan silahlı çatışma olarak sınıflandırılabilmesi için gereken iki kriter, yukarıda açıklandığ 1 gibi i) çatışmalara dahil tarafların belli bir örgütlenme düzeyine sahip olması ve ii) şiddetin belli bir yoğunluğa ulaşmış olması şeklinde kabul görmektedir. ${ }^{53}$ Bu doğrultuda, Görüş Belgesi, bir devlet-dışı silahlı grubun bir uluslararası nitelikte olmayan silahlı çatışmaya taraf olarak isimlendirilebilmesi için örgütlenme kriterini karşılaması gerektiğini bildirmektedir. Buna göre, uluslararası insancıl hukuk, uluslararası nitelikte olmayan bir silahlı çatışmanın "taraflarından" söz etmektedir ve devlet veya devlet-dışı grup ayrımı yapmamaktadır, zira bir silahlı grubun bu yola başvurmaktaki amaçları veya kimin haklı veya haksız olabileceği gibi değerlendirmeler uluslararası insancıl hukukun ilgi alanına girmemektedir. ICRC'nin pozisyonunu bu şekilde açıklayan Görüş Belgesi'nde, bu türden devlet-dışı silahlı grupların gerek birçok uluslararası ve bölgesel enstrümanlarda gerek iç hukuk düzenlemelerinde terörist örgüt listelerinde yer almalarının, bunlarla insancıl amaçla angajmana giren ICRC çalışanları için yasal sonuçları bulunan bir tehlike oluşturduğu söylenmektedir. Zira, bu grupların kontrolü altında bulunan bir ülke kesiminde gıda maddeleri dağıtmak, çeşitli enstrümanlarda terörist olarak sınıflandırılan tutukluları ziyaret etmek, hors de combat durumdaki yaralı ve hastaları tedavi etmek veya bu gruplara insancil hukuk kurallarını anlatan eğitimler düzenlemek, birçok devletin iç hukukunda, terör örgütlerine destek ve yardım gibi suçları teşkil ederek cezalandırılmayı gerektirecektir. Görüş Belgesi’nde ayrıca, ICRC’nin bu faaliyetlerinden ötürü sadece çalışanlarının bireysel yönden yasalar önünde cezalandırılmasından değil, ayrıca ICRC'nin (veya benzer faaliyet gösteren insancıl organizasyonların) da kurum olarak özellikle bir takım malî yaptırımlara uğrayabileceğinden veya bağışlardan yoksun kalacağından endişelendiği de görülmektedir. Görüş Belgesi’nde bu durumun 150 yıl önce ICRC’nin kurulma hedefleriyle çeliştiği ifade edilmektedir.

\section{DEĞERLENDIRME}

1949 Cenevre Sözleşmeleri’nin Ortak 3'üncü Maddesinin 2'nci fikrasında öngörülen ICRC ve benzer insancıl organizasyonların, bir iç çatışmada taraflara hizmetlerini teklif etmesi hakkı, Cenevre Sözleşmeleri'nin 9/9/9/10'uncu Maddesinin, uluslararası nitelikte olmayan silahlı çatışmalarda uygulanmak üzere uyarlanmış halidir ve dört Sözleşme’de de yer almıştır. 9'uncu Madde Sözleşme’ye konulurken temel alınan düzenleme ise 1929 Savaş Esirleri Sözleşmesi’nin 88'inci Maddesi olmuştur. 1929 Sözleşmesi'nin 88'inci Madde düzenlemesi, ICRC’nin Birinci Dünya Savaşı sırasındaki faaliyetlerini model almıştır. 1914 yılında çatışmalar henüz yeni başladığı sırada ICRC, daha önceki çatışmalarda sahip olduğu deneyimlere de dayanarak, Cenevre'de bir Harp Esirleri Merkez Ajansı oluşturmuş ve yakalanan askerler ile onların izini kaybeden aile üyelerinin bağını tekrar tesis etmeye çalışmıştır. Buna ilaveten, Lahey düzenlemelerinin verdiği

52 Ibid., ss. 11-12.

53 31st International Conference of the Red Cross and Red Crescent, "International Humanitarian Law and the Challenge of Contemporary Armed Conflicts”, ICRC Report, 2011, s. 8. https://www.icrc.org/en/doc/assets/files/red-cross-crescentmovement/31st-international-conference/31-int-conference-ihl-challenges-report-11-5-1-2-en.pdf. (13.03.2021) 
yetkiyi de kullanmak suretiyle yardım faaliyetlerinde bulunmuş ve enternelerin tutulduğu kamplara delegelerini göndermiştir. ${ }^{54}$

1949 yllına gelindiğinde uluslararası silahlı çatışmalar açısından, ICRC'nin veya herhangi bir tarafsız teşkilatın, çatışmanın taraflarının rızasıyla "yaralı ve hastalar ile sağlık ve dinî teşkilât üyelerini korumak için girişeceği insanî çalışmalara” engel olmayacağı yönünde bir düzenleme kabul edilmiştir. ${ }^{55} \mathrm{Bu}$ hükmün benzerinin ortak 3'üncü Maddede de yer alması ICRC tarafından memnuniyetle karşılanmıştır, zira uluslararası nitelikte olmayan silahlı çatışmalar açısından tarafsız bir yardım kuruluşunun taraflara hizmetlerini teklif etme hakkının kabul edilmesinin bazı yararları olduğu düşünülmüştür. ${ }^{56}$ Şöyle ki bu hüküm, ICRC veya diğer bir aynı işlevde örgütün insancıl yardım teklifi için yasal bir zemin oluştururken, bir devletin içişlerine hiç de dostça olmayan bir müdahale teşkil ettiği gerekçesiyle de reddedilemeyecektir. ${ }^{57}$ Tabii tarafların her halükarda bu tür bir yardım teklifini kabul etme zorunlulukları yoktur ve ortak 3'üncü Maddenin gereklerini yerine getirme görevi öncelikle tarafların yükümlülügüdür. ${ }^{58}$ Diğer yandan her ülkenin kendi Ulusal Kızılhaç veya Kızılay Toplulukları da bir iç silahlı çatışma sırasında ortaya çıkan yardım ulaştırma ihtiyaçlarına cevap vermekle görevlidir. Ancak ulusal toplulukların kapasitesinin yetersiz kalması durumunda ek yardım gerekebilir. Böyle bir durumda insancıl yardım teklifini geri çeviren bir çatışma tarafı, ağır bir ahlaki sorumluluk altında kalacaktır. ${ }^{59}$

1949 Cenevre Sözleşmeleri’nin Jean Pictet editörlügüunde hazırlanan ve 1952'de yayımlanan ilk şerhleri okunduğunda, ICRC’nin yaklaşımında, 1949 Sözleşmeleri’nin yapıldığ zaman ile Görüş Belgesi’nin yayımlandığı Mart 2021 arasında temel esaslar yönünden herhangi bir fark bulunmadığı anlaşılmaktadır. Bu temel esaslar üzerinde hemen herkes uzlaşmakla birlikte bunların uygulanmasıyla ilişkili bazı temel anlayış farklııkları gözlemlenebilir. Görüş Belgesi’nde genel hatlarıyla ICRC’nin iç silahlı çatışmalarda sivillere yardım ulaştırması yükümlülügünden ve bunu hangi unsurlarıyla yerine getirdiğinden söz edilmektedir. Görüş Belgesi’nde yer alan bu hususlar, ICRC nin önceki çalışmalarıyla ve özellikle de 2009 yılında derlenen Yorumlayıcı Rehber ile birlikte ele alındığında neden çeşitli görüş ayrılıklarının ortaya çıktığı daha iyi anlaşılabilir.

Bilindiği gibi uluslararası nitelikte olmayan silahlı çatışmalarda Sözleşmeler'den kaynaklı bir savaşçı (combatant) kavramına/statüsüne yer verilmemiştir. Aslen uluslararası silahlı çatışmalar için tespit edilmesi mümkün olan bu statüye kimlerin sahip olacağı ise dolaylı olarak III No.'lu Harp Esirlerine Yapılacak Muamele ile ilgili Cenevre Sözleşmesi’nin 4'üncü Maddesinden yola çıkarak tespit edilebilir.

54 Jean S. PICTET (Ed.), Convention (I) for the Amelioration of the Condition of the Wounded and Sick in Armed Forces in the Field. Geneva, 12 August 1949, Commentary, Geneva, 1952. s. 103.

55 Harp Halindeki Silahlı Kuvvetlerin Hasta ve Yaralılarının Vaziyetlerinin Islahı Hakkında Cenevre Sözleşmesi, Madde 9; Silahlı Kuvvetlerin Denizdeki Hasta, Yaralı ve Kazazedelerinin Vaziyetlerinin Islahı Hakkında Cenevre Sözleşmesi, Madde 9; Harp Esirlerine Yapılacak Muamele ile ilgili Cenevre Sözleşmesi, Madde 9, Harp Zamanında Sivillerin Korunmasına ilişkin Cenevre Sözleşmesi, Madde 10

56 Commentary 1952, supra dn. 54, s. 48.

57 Ibid.

58 Ibid., s. 58 .

59 Ibid. 
Ancak, uluslararası nitelikte olmayan silahlı çatışmalar yönünden de kimlerin bir iç silahlı çatışmaya varan boyuttaki şiddet eylemlerine aktif şekilde katıldığını tespit edip bunları sivil halktan ayırmak önem taşır, zira aksi takdirde uluslararası insancıl hukukun temelinde yatan ayırt etme ilkesinin uygulanma imkânı kalmaz.

$\mathrm{Bu}$ nedenle, uluslararası nitelikte olmayan silahlı çatışmalar açısından da ayırt etme ilkesinin uygulanabilmesi yönünden bir savaşçı (fighter)/sivil ayrımından söz etmek gerekli görülmüştür. Burada, bir iç silahlı çatışmada pratik amaçlarla savaşçı olarak nitelendirilmek, bu kişilere iç hukukta öngörülenden farklı bir ayrıcalık veya statü sağlamaz. İç hukukta bu kişiler için terörist veya isyancı veya diğer bir sınıflandırmanın varlığı, pratik sebeplerle yapılan savaşçı/sivil ayrımı ile ters düşmez. Yakalandıkları takdirde savaş esiri veya benzeri ayrıcalıklardan yararlanmalarına imkân bulunmaz, zira Sözleşmeler'de savaş esirleri düzenlemesi yalnızca uluslararası nitelikte silahlı çatışmalar açısından öngörülmüştür. Uluslararası silahlı çatışmaların aksine, iç silahlı çatışmalarda çatışma fiillerine katılan kişiler sırf bu nedenle yargılanıp cezalandırılabilirler. Tabii tüm bu prosedürlere uluslararası ve bölgesel insan hakları antlaşmalarının sağladığı güvencelerin de uygulanacağı bilinmektedir.

Anılan bu temel hususlarda ICRC’nin yaklaşımı ve devletler arasında genellikle görüş ayrılıkları bulunmamaktadır. Yukarıda belirtildiği gibi silahlı çatışma fiillerine karışan kişilerin belirlenmesi ve bu kişilere insancıl hukukun sivillere sağladığı korumanın ne şartlarda uygulanacă̆ gibi konularda ICRC'nin yaklaşımı ile birçok devletin ve yetkin uzmanların yaklaşımları arasında ise önemli farklılıklar bulunmaktadır. Bu farklılıkların özellikle ortaya çıktığı durum, Görüş Belgesi’nde sivillere yardım amacı dikkate alındığında, sivil sınıflandırmasının muğlak bir niteliğe bürünmesidir ("revolving door" of civilian protection).

Geçmiş çalışmalarından dolayı, uluslararası nitelikte olmayan bir silahlı çatışmaya ilişkin olarak ICRC’nin sivil tanımının, belirli bir zaman dilimi içerisinde (for such time) muhasamata doğrudan katılmayan şahısları kapsadığı hatırlanabilir. ICRC’nin zaman zaman muhasamata doğrudan katılan şahıslarla ilgili yaptığı, her bir olaya ilişkin olarak kişinin "sivil” veya "savaşç” statüsünün belirlenmesi değerlendirmesi yetkin uzmanlar tarafından da eleştirilmiştir. ${ }^{60}$ Sivillerin korunmasında bu tür bir "döner kapı” anlayışının, hedef belirlenirken verilebilecek keyfi kararlara karşı en üst düzeyde koruma sağladığını ileri süren yazarlar da bulunmaktadır. ${ }^{61} \mathrm{Bu}$ tarz bir çözüm, bu yazarlara göre,

60 SCHMITT, 2010, ss. 16-18. Diğer eleştirel yaklaşımlar için ayrıca bkz. Kenneth WATKIN, "Opportunity Lost: Organised Armed Groups and the ICRC 'Direct Participation in Hostilities' Interpretive Guide”,

NYU Journal of International Law and Politics, 2010, ss. 641-693; Bill BOOTHBY, “'And For Such Time As': The Time Dimensions to Direct Participation in Hostilities",

NYU Journal of International Law and Politics, 2010, ss. 741-768; W. Hays PARKS, "Part IX of the ICRC "Direct Participation In Hostilities" Study: No Mandate, No Expertise, and Legally Incorrect", NYU Journal of International Law and Politics, Vol. 42, 2010, ss. 769-830.

61 Nils MELZER, "Keeping the Balance Between Military Necessity and Humanity: A Response to Four Critiques of the ICRC's Interpretive Guidance on the Notion of Direct Participation in Hostilities", NYU Journal of International Law and Politics, 2010, s. 867. (831-916); Shannon BOSCH, "The International Humanitarian Law Notion of Direct Participation in Hostilities - A Review of the ICRC Interpretive Guide and Subsequent Debate", PER / PELJ, Vol. 17, No 3, 2014, s. 1039. 
uluslararası insancıl hukukun temel ilkeleri, özellikle ayırt etme ve gereksiz acıların engellenmesi, ile tam bir uyum içindedir. ${ }^{62} \mathrm{Bu}$ görüşün savunucuları, "sürekli bir savaş işlevi" (continuous combat function) kavramının, "gündüz çiftçi, gece savaşçı" (farmer by day, fighter by night) sakıncasını ortadan kaldırmaya yeterli olduğunu düşünmektedirler. Buna göre, sürekli bir savaş işlevi yerine getiren devlet-dışı silahlı grubun üyeleri, çatışmanın taraflarından birine münferiden dolaylı destek veren kişilerden kolayca ayrılabilir ve bu ikinci grup kişiler, siviller olarak askeri saldırılara karşı korunurlar.

Bu görüsşe karşı Schmitt, haklı olarak her bir operasyonda, hedef alınan kişilerin her biri için, "sürekli bir savaş işleviyle" mensubiyet ve bunun son bulduğu durumların değerlendirilmesinin uygulamada mümkün olmadığını ileri sürmektedir. ${ }^{63}$ Buna göre, örgütlü bir silahlı grubun sürekli bir savaş işlevi yerine getiren üyeleri, her an askeri bir hedef olabilirken bu örgütle ilişkili olarak münferiden silaha sarılan şahıslar sivillere sağlanan korumadan yararlanmalıdırlar ve ancak silaha sarıldıkları zaman diliminde hedef alınabilirler. İşte Schmitt bu iki kategoriyi ayırt etmeye çalışmanın uygulamada mümkün görünmediğini vurgulamıştır. Zira bir kişi devlet-dışı bir silahlı grubun içerisinde silahlı bir çatı̧̧maya katıldı ise, devlet kuvvetleri bu gruba karşı bir sonraki operasyonu planlarken söz konusu kişinin belirli aralıklarla mı yoksa sürekli mi çatışmalarda yer aldığını gerçekten tespit edemeyecektir. ${ }^{64}$

Bu doğrultuda, bir iç silahlı çatışma durumunda, devletlerin zaten çoğu zaman terörle ilişkili yasaları altında terrorist olarak sınıflandırdığı kişilerle ilgili, devletlerin daha fazla çekimserliğine yol açacak sınıflandırmalar yapmak yardımcı olmaktan çok zorluğa yol açabilir. Zira uluslararası nitelikte olmayan bir silahlı çatışmaya uyarlanan "sivil" ve "savaşçı" kavramlarının, geçişli bir nitelik taşıması, ICRC’nin insancıl yardımlarının kimlere yönelik olduğu hakkında daha fazla endişeye yol açabilir.

\section{SONUÇ}

Uluslararası nitelikte olmayan bir silahlı çatışmada askeri saldırıya karşı korunacak ve ICRC nin amaçları açısından insancıl yardım ulaştırılacak kişi kategorisinin böyle bir esneklik ve değişkenlik göstermesi, ICRC’nin insancl hizmetlerini sunma hakkındaki teklifini devletlerin geri çevirmesinde bir sebep olarak ortaya çıkabilir. Şüphesiz ICRC’nin uluslararası insancıl hukuk enstrümanlarının yorumunda ve uygulanmasında katkısı çok büyüktür. Fakat devletlerin taraf oldukları antlaşmalarda açıkça bildirilmeyen hususların, yorumlayıcı soft-law belgeler aracılığıyla uygulamada birer yükümlülük olarak ortaya konulmasının kısmen zararlı sonuçları da olabilir. Bu eğilim nedeniyle devletler, özellikle silahlı çatışmalar konusunda antlaşmalara taraf olmaktan imtina eder hale gelebilir. Özellikle de uluslararası nitelikte olmayan bir silahlı çatışmada hükümet güçlerinin, devlet-dışı silahlı gruplardan adeta daha dezavantajlı bir duruma gelmesine yol açacak yorumlarda

62 BOSCH, 2014, s. 1039.

63 SCHMITT, op. cit. s. 23.

64 Ibid. 
bu tehlike daha fazla ortaya çıkabilir. Bu da uluslararası insancıl hukukun sivillerin korunması ve gereksiz acıların giderilmesi amaçlarına hizmet eden bir sonuç olmayacaktır.

\section{KAYNAKÇA}

31st International Conference of the Red Cross and Red Crescent, "International Humanitarian Law and the Challenge of Contemporary Armed Conflicts”, ICRC Report, 2011. ttps://www.icrc.org/en/doc/assets/ files/red-cross-crescent-movement/31st-international-conference/31-int-conference-ihl-challengesreport-11-5-1-2-en.pdf. (13.03.2021)

BATUR YAMANER, Melike et al., 12 Ağustos 1949 Tarihli Cenevre Sözleşmeleri ve Ek Protokolleri, Galatasaray Üniversitesi Hukuk Fakültesi Yayını 42, İstanbul.

BOOTHBY, Bill, “'And For Such Time As': The Time Dimensions to Direct Participation in Hostilities”, NYU Journal of International Law and Politics, 2010, ss. 741-768.

BOSCH, Shannon, “The International Humanitarian Law Notion of Direct Participation in Hostilities - A Review of the ICRC Interpretive Guide and Subsequent Debate", PER / PELJ, Vol. 17, No 3, 2014, ss. 999-1046.

HENCKAERTS, Jean-Marie ve Louise DOSWALD-BECK, Uluslararası İnsancıl Teamül (Örf-Adet) Hukuku, Cilt I: Kurallar, (çev) A. Emre ÖKTEM et al., Galatasaray Üniversitesi Hukuk Fakültesi Yayınları 66, İstanbul, 2005.

ICRC Engagement with Non-State Armed Groups: Why, how, for what purpose, and other salient issues ICRC Position Paper, March 2021. https://www.icrc.org/sites/default/files/wysiwyg/Activities/Humanitariandiplomacy/icrc_engagement_with_non-state_armed_groups_position_paper.pdf. (13.03.2021)

ICRC, Commentary on the First Geneva Convention: Convention (I) for the Amelioration of the Condition of the Wounded and Sick in Armed Forces in the Field, 2nd edition, 2016, https://ihl-databases.icrc.org/ ihl/full/GCI-commentary. (13.03.2021)

International Criminal Court (ICC), Elements of Crimes, 2011, https://asp.icc-cpi.int/iccdocs/asp_docs/ Publications/Compendium/ElementsOfCrime-ENG.pdf. (13.03.2021)

KURTDARCAN, Bleda Rıza, Muharebe Alanının Yeni Aktörleri: Askeri Yükleniciler, Beta, İstanbul, 2017.

LAWAND, Kathleen, Interview - What is a non-international armed conflict?, https://www.icrc.org/en/doc/ resources/documents/interview/2012/12-10-niac-non-international-armed-conflict.htm. (13.03.2021)

MELZER, Nils, "Keeping the Balance Between Military Necessity and Humanity: A Response to Four Critiques of the ICRC's Interpretive Guidance on the Notion of Direct Participation in Hostilities", NYU Journal of International Law and Politics, 2010, ss. 831-916.

MELZER, Nils, Interpretive guidance on the notion of direct participation in hostilities under international humanitarian law, ICRC, 2009. http://www.icrc.org/eng/assets/files/other/icrc-

ÖKTEM, Emre, Terörizm, İnsancıl Hukuk ve İnsan Hakları, Derin Yayınları, İstanbul, 2007.

PARKS, W. Hays, "Part IX of the ICRC "Direct Participation In Hostilities" Study: No Mandate, No Expertise, and Legally Incorrect", NYU Journal of International Law and Politics, Vol. 42, 2010, ss. 769-830.

PICTET, Jean S. (Ed.), Convention (I) for the Amelioration of the Condition of the Wounded and Sick in Armed Forces in the Field. Geneva, 12 August 1949, Commentary, Geneva, 1952.

SANDOZ, Yves /Christophe SWINARSKI/Bruno ZIMMERMANN, Commentary on the Additional Protocols of 8 June 1977 to the Geneva Conventions of 12 August 1949, ICRC, Geneva, 1987.

SCHMITT, Michael, "The Interpretive Guidance on the Notion of Direct Participation in Hostilities: A Critical Analysis", Harvard National Security Journal, Vol. 1, 2010, ss. 5-44. 
TAŞDEMİR, Fatma, Uluslararası Nitelikte Olmayan Silahlı Çatışmalar Hukuku, Adalet Yayınevi, Ankara, 2009. TÜTÜNCÜ, Ayşe Nur, İnsancıl Hukuka Giriş, Beta, İstanbul, 2006.

VITE', Sylvain, "Typology of armed conflicts in international humanitarian law: legal concepts and actual Situations", International Review of the Red Cross, Volume 91 Number 873 March 2009.

WATKIN, Kenneth, "Opportunity Lost: Organised Armed Groups and the ICRC 'Direct Participation in Hostilities’ Interpretive Guide”, NYU Journal of International Law and Politics, 2010, ss. 641-693. 